\title{
TECHNOLOGY LEADERS OF COMPUTER AND WEB 2.0 USAGE IN HIGHER EDUCATION: CASE STUDY
}

\author{
Zoran Marošan", Novi Sad Business School \\ Borislav Jošanov, Novi Sad Business School \\ Ninoslava Savić, Novi Sad Business School
}

\begin{abstract}
Development of ICT usage and open concepts brought new learning paradigm of knowledge creation to the higher education. Main role in this new concept in infrastructure aspect is reserved for web 2.0. The authors of this paper present the case study with the experience of students in the higher education institution. In the first part of the study authors analyze the data collected from the students related to Internet access and Internet activities from them. This research was conducted using questionnaires based on indicators defined by Eurostat and data authors found in the students' projects created by web 2.0 tools. The main part and purpose of this paper is to analyze how students in Serbia are using web 2.0 tools in their research work. Authors found trends in web 2.0 tools usage and the most popular technologies, concluding that web 2.0 tools are speeding the process of projects development.
\end{abstract}

Key words: Web 2.0, computer usage, technology leaders, higher education, students.

JEL classification: L86

\section{TEHNOLOŠKI LIDERI UPOTREBE RAČUNARA I VEBA 2.0 U VISOKOM OBRAZOVANJU: STUDIJA SLUČAJA}

Sažetak: Razvoj upotrebe IKT i otvorenih koncepata je donelo visokom obrazovanju novu učeničku paradigmu kreiranja znanja. Glavna uloga u ovom novom konceptu sa aspekta infrastrukture je dodeljena Vebu 2.0. Autori ovog rada predstavljaju studiju slučaja sa iskustvima studenata institucije visokog obrazovanja. U prvom delu rada autori analiziraju od studenata prikupuljene podatke koji se odnose na pristup Internetu $i$ njihovim aktivnostima na Internetu. Ovo istraživanje je sprovedeno korišćenjem upitnika zasnovanim na indikatorima definisanim od strane Eurostata kao i podacima koje su autori našli u studentskim projektima kreiranim korišćenjem alata Veba 2.0.

\footnotetext{
*z.marosan59@gmail.com
} 
33 | TECHNOLOGY LEADERS OF COMPUTER AND WEB 2.0 USAGE IN HIGHER EDUCATION: CASE STUDY

Glavni cilj ovog rada je da se analizira kako studenti u Srbiji koriste alate Veba 2.0 u njihovom istraživačkom radu. Autori su uočili određene trendove $u$ korišćenju alata Veba 2.0 i najpopularnijih tehnologija, zaključujući da alati Veba 2.0 ubrzavaju proces razvoja projekata.

Ključne reči: Veb 2.0, upotreba računara, tehnološki lideri, visoko obrazovanje, studenti.

\section{INTRODUCTION}

The world is becoming increasingly connected place today. Digitalization in telecommunication sector created long time trend of intensive integration and development of information and communication technologies (ICT). As the Internet continues to evolve, new ICT and application solutions constantly appear in our practice, with the Web in the core of these technologies. In 17 years period, Web, as the main part of the implementation of new technologies, has grown from the scientist's group work tool into a global information space. Intensive development of modern ICT has caused thorough changes in all aspects of life including the state and conducting.

New ICT caused a dramatic change in the way people live, learn and work and this process is accompanied by social, industrial, and organizational reconstructions and innovations. The social web (Web 2.0) is a set of social relations that link people through the World Wide Web. In the period when the social web concept was introduced, it became more important than ever to enter into a new, more social and participatory phase, with new, open wave on innovations coming to the surface, as Von Hippel (2005) points it. Among different processes that are involved in this innovation wave, authors found learning as one of the most significant parts.

That is why the main contents of this paper describe the development of learning metaphors and concepts of social web, important for new learning processes. Finally, authors present the case study in Higher Business School for Professional Studies in Novi Sad (HBSNS), with the student experiences found in this higher education institution.

\section{NEW LEARNING METAPHOR}

Reflection and meta-cognition are essential aspects of constructing knowledge, where designers have to conceptualize learning experiences that students can personalize. Design activities for knowledge sharing among students are a major source of content and pedagogy. As a consequence, learning activities should enable learners to access their experiences, knowledge, and beliefs. In the core of those aspects of learning, authors find a social activity that is 
enhanced by shared inquiry, but education is also a two-sided transaction where effective use of technology requires special institutional organization. New technologies are generally very helpful in the most of learning activities and they are used for common ways of teaching for a years, but this other direction of transactions that are coming from the learners is specially forced by the Internet new ICT, opening the space for new models of active participation for both sides in education process.

Openness in education is becoming a new hype or a paradigm shift. In the recent years, the term "open" has been used as a variety of contexts that describe teaching and learning materials. As Wiley (2010) concludes, "open content, open educational resources, open courseware, and open textbooks are all part of the current higher education discourse". Social web brings important cultural changes, with the openness as hallmark. Software infrastructure is based on open source, while open content of metadata is in the form of micro contents.

In this new context, with the ICT as a facilitator, authors can find two wellknown learning metaphors defined by Sfard (1998) and the third that is coming from the activity theory. The first two metaphors of learning are acquisition and participation and they are creating the basics for various models and theories of learning. According to these metaphors, existing written knowledge has to be reconstructed in educational institutions in the way that it will build new knowledge within communities. The acquisition metaphor relies on the idea that knowledge is a property of an individual mind, while the participation metaphor assumes that learning is an interactive process of participating in shared learning activities. According to Paavola et al. (2004), knowledge creation metaphor is a third main metaphor of learning becoming more important in modern society, explaining how knowledge advancement takes place. They see learning as analogous to innovative processes of inquiry where something new is created and the initial knowledge is either substantially enriched or significantly transformed during the process. The first, acquisition metaphor emphasize individuals and conceptual knowledge, participation metaphor highlights interactions, meaning making process and situated cognition, while knowledge creation metaphor underline practices and artifacts developed collaboratively. This third metaphor is in the core of new learning models, based on intensive use of ICTs.

Following that track, authors are coming to the advent of digital campus, what caused that numerous changes have occurred. As we are in the phase of early developments, we are able to improve efficiencies and eliminate the need for human intervention to conduct routine activities (Wankel, \& Wankel 2011). 

CASE STUDY

\section{SOCIAL WEB CONCEPT}

Today we are not remembering what people had to do to find the answer to a question before the Web (Chi, 2012). In the last decade, it is possible to find that much more people use the web instead of books, yellow pages, or libraries to search for information. Information overload is the result of billions of web pages published on servers worldwide, bringing the lack of well-organized filtering and classification services.

Social media and Web 2.0 technologies change the distribution of information, where users must realize that they are structurally embedded in online networks of interconnected and equitable actors (Fieseler, \& Fleck, 2013). Creator of the web Tim Berners-Lee said: "I have always imagined the information space as something to which everyone has immediate and intuitive access, and not just to browse, but to create". Those visionary words are beginning to be fulfilled since 2005, when the landscape of Internet mapping technologies has changed dramatically and new techniques are used. In that period whole range of web sites, communities and applications have emerged, created according to the people-to-people paradigm called Web 2.0 or social web. The term Web 2.0, coined by Dougherty and O'Reilly, is often applied to a heterogeneous mix of relatively familiar and emergent technologies, with the idea of harnessing the collective intelligence of crowds to give information a value (O'Reilly, 2007). We can say that key elements of Web 2.0 include:

- Really Simple Syndication (RSS) are rapidly disseminating awareness of new information;

- blogs are describing new trends;

- wikis are main part in sharing knowledge; and

- podcasts are helping with the idea to make information available "on the move".

Result of this process is the actual Social web movement, based on the concepts of micro content and openness that are combined into a larger conceptual strand. Thus, we come to the new role for users, playing more of a foundational role on "the wisdom of the crowds" argument. This new platform responds deeply to its users in a new form of metadata called folksonomy, organized on the sets of words generated by users and attached to the contents. In this way, social web gives the opportunity to any user to take part in creation of huge amount of contents in the database behind. The focus of this widely read-write Web is on the power of community to create and validate metadata. Forms of these folksonomies have free forms of organization, based on tags, with different "hooks" that are set up to be used in future integration. 
This idea about the creation of collective intelligence placed in the database behind the web technologies is very important for the success of this complex group of different solutions. Dominantly social web is a social change, where technical part of the Web has not change very much. Functionally, it is about the power of networks: links, collaboration, content and reach, and friends.

In the most of the cases, after a period of searching for the best solutions, they are reshaped into blogs, wikis, video presentations, web feeds etc. When computer networks link people like machines, we call them social networks (Wellman et al., 1996). Network with people in the nodes and relations between them as the ties is the infrastructure that is used for virtual communication. According to Turban and Volonino (2010), social network is a place where people create their own space or home page where they write blogs, post pictures, videos and music, share ideas and link to the other persons. These new types of social media tools are creating an opportunity to share or aggregate data, but also giving a chance to the users to be part of the authoring process (Jošanov et al., 2010). In this moment, when we speak about development of social web, we do not think about new theories or some fundamental concepts within theories, but we can describe it as some shift in how we view the web.

The road to find solutions for these issues leads to the systematic approach for introduction of social web technologies into the formal learning system of higher education institutions. Social web needs new social media tools that are in increasing use across higher education. Integral use of Web 2.0, cloudcomputing technology and its use in education has the common aim to provide best services with blogs, RSS, instant messaging, social networking services, wikis, and social tagging applications. Speaking about higher education, authors found that live blogs, Facebook events, Wiki contents, YouTube multimedia recordings, Twitter hash tags, and Flickr groups are becoming a regular feature of academic conferences and events.

Looking at the gamma of online applications used in education processes, education professionals felt that virtual learning networks, video sharing and online event scheduling are the most important educational Web 2.0 applications (Pritchett et al., 2013).

To implement Social web in higher education authors find many new issues. According to Sangeeta Namdev (2012), ICT caused drastic changes in all service sectors along with higher education, where the academic environment is changing from formal education to distance and online learning mode. Thus, the integration of public domain software in education process brings the problems of information quality and sustainability, without the formal owner and guarantee. That is fostering the question which objects or tools from social web are justified in terms of learning objectives. Hew and Cheung (2013) discuss BUSINESS SCHOOL, 2/2015, 32 - 48 

CASE STUDY

pedagogical approaches related to the use of Web 2.0 technologies in higher education settings, finding that actual evidence regarding the impact of Web 2.0 technologies on student learning is as yet fairly weak, but the use of Web 2.0 technologies appears to have a general positive impact on student learning. Those positive effects are not necessarily attributed to the technologies, but how the technologies are used in pedagogical processes. Web 2.0 can be efficiently applied is in higher education, where the most of students have embraced Web 2.0 and use it in education process and everyday' life by changing the way they communicate within and outside of school, through many Web 2.0 tools (Peštek et al., 2012).

Users of Web 2.0 tools have a new nickname: Students 2.0, well-known as self learners, self searchers, fast communicators, self publishers, and self motivated (Sangeeta Namdev, 2012).

Social web and academic ethos are two opposite sides in many aspects, but the main question is how much meta noise in information can be tolerated. That is why the response to the opportunity and challenge of social web is still measured in individual cases, but not in a common practice.

\section{RELATED WORKS AND FRAMEWORK}

Among the top interests of researchers today is Web 2.0 (social web), analyzed in many papers. In the paper of Anderson (2010), the key objective is to examine the work in this area and to tease out some of the key elements, like the needs to have a distinction between concerns around quality of service and usercentered change, services and applications that have been driven by social web ideas. In their visionary paper, authors discuss about adaptive and intelligent Web-based educational systems, which have to provide an alternative to the traditional just-put-it-on-the-Web approach in the development of Web-based educational courseware (Brusilovsky, \& Peylo, 2003). Greenhow (2007) reports on common uses of Web 2.9 in education process, with the idea to shape the direction of the field, with the implications for the design of future research, where teacher education initiatives are discussed in details. Developments in the Semantic Web also raise new issues that analyzed in Web-based educational applications (Devedžić, 2004).

Another paper analyzes the notions of emergence, connections, and designs for learning to conceptualize high school students' interactions when using online social media as a learning environment (Casey, \& Evans, 2011). The group of authors visualizes challenges in tourism that are associated with the developments of the social web out of a scientific and practical point of view (Amersdorffer et al, 2012). According to the group of authors, program planners need to be creative in their promotion efforts and consider how Web 2.0 social 
media can be incorporated to better market their products to the intended priority population (Thackeray et al., 2008).

McLean, Richards and Wardman (2007) found in their research that Web 2.0 is a "revolutionary way of managing", but they also think that we have to take care about cautious thinking, testing and evaluation research that are still needed in order to establish "best practice models" for leveraging these. Chou et al. (2013) in their study explored seven constructs: purposive value, hedonic value, social identity, social support, interpersonal relationship, personality traits, and intimacy as the factors predicting Facebook and Google usage. Ahrens et al. (2010) analyze the students' view on the relationship between social dimension of Web 2.0 technologies and e-learning within education. Another research investigates physical education undergraduate students' views on the use of social networking, one of the most typical representations of Web 2.0 technologies (Sezen Balcikanili, 2012).

Our research was conducted in a period of three years: 2010, 2011 and 2013, with the students at HBSNS. The research has two parts. In the first part, authors collected and processed the answers on the questions taken from the Eurostat standard methodology that takes part every year. The results of this part of the research are presented as percentages of the conducted population. After that, they are compared with the results of Eurostat investigation, taken on the similar group of the examinees. Second part of this research was implemented on the results of student projects created during the exercises in the teaching process, where students were addressed to use social web tools for their research process. The results presented in this part of the research show the percentage of different social web tools participation in students project research.

The goal of our research, whose results are discussed in this paper, was to find how students see and use different social web tools for research process. For this purpose, authors took three groups of students in three different, previously mentioned years and they gave them the task to do research in the area they choose using the social web tools and to make the study referring to the social web tools used during the research. After they finished their research, authors analyzed the results. Some statistics of these results are presented roughly in the following part of text. In 2010, authors analyzed project results of 92 studies; there were 102 in 2011, and 89 in 2013.

At the same time, the authors collected some basic data related to Internet access and Internet activities from them. They based our questionnaire on indicators defined by Eurostat in the field of Information society (Eurostat, 2014). Authors will present in the following text some of those data. 

CASE STUDY

\section{COMPUTER USAGE IN HBSNS}

HBSNS is the second largest higher business school in Serbia. It is connected to the National Research and Education Network, the Internet backbone network for academic purposes in Serbia. The information system of HBSNS is designed with intranet and database as a main infrastructure. Multiple channels for student services could be available for student use: face-to-face, information board, fixed phone, information kiosks, web site and SMS message center. All the information is coming from the same origin - database in the back, and multi-channel organization of information infrastructure gives good opportunity to the students to choose how they will get their information. Students can find information about syllabus, course contents, literature, schedules for studies and examinations, and a lot of other useful information. On the other hand, there are e-classrooms for presentations, exercises, team and own work of students, all of them connected with the Internet.

Students are very familiar with computer usage for different purposes. That is why the school created their internal space for group work and communication. On the first level of that solution, authors have an account on Facebook, where almost all students are members. On the lower level, they create blogs with their projects as main texts and comments of other students. Wikis are used for creation of final versions of projects, in a long tail manner. Multimedia presentations are found with YouTube, while pictures are taken from Flickr and Instagram. This way, students have an integrated environment for the presentation of their results.

In the research phase, students are also stimulated to use social web for their investigations. During their lessons in Basics for e-business, they were stimulated to use social web tools to make research in the field they have chosen.

As authors expected for a student population, their households had a very high and still growing percentage of Internet access, 91.83\% in 2010, 96.21\% in 2011 and finally $97.03 \%$ in 2013 (figure 1). Since this percentage already reached a very high level, we do not expect major rise in the future period.

Similar are the figures concerning the last Internet use. In 2010, 97.80\% of all students used Internet in last three months, $98.23 \%$ in the next year and finally $98.53 \%$ in 2013. The number of students that accessed Internet more than a year ago is dropping, from $1.65 \%$ in 2010 to $0.74 \%$, but we found still this situation a little surprising regarding the fact that all students can access Internet from our school.

Concerning the frequency of Internet access in the last three months, accessing Internet became a daily routine for almost all students. The percentage of those 
who do it every day or almost every day was $88.72 \%$ in $2010,88.39 \%$ in 2011 and raised to $94.03 \%$ in 2013 (figure 2). There were no significant changes in the group of those that accessed Internet at least once a week, but the figures show an important drop of students that accessed Internet at least once a month, from $5.13 \%$ in 2010 to $0.75 \%$ in 2013.

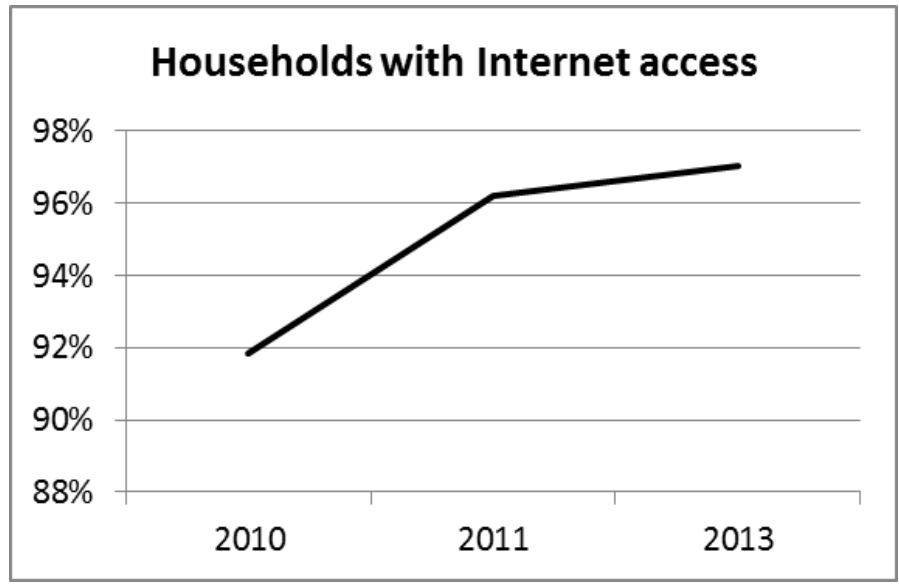

Figure 1. Households with Internet access

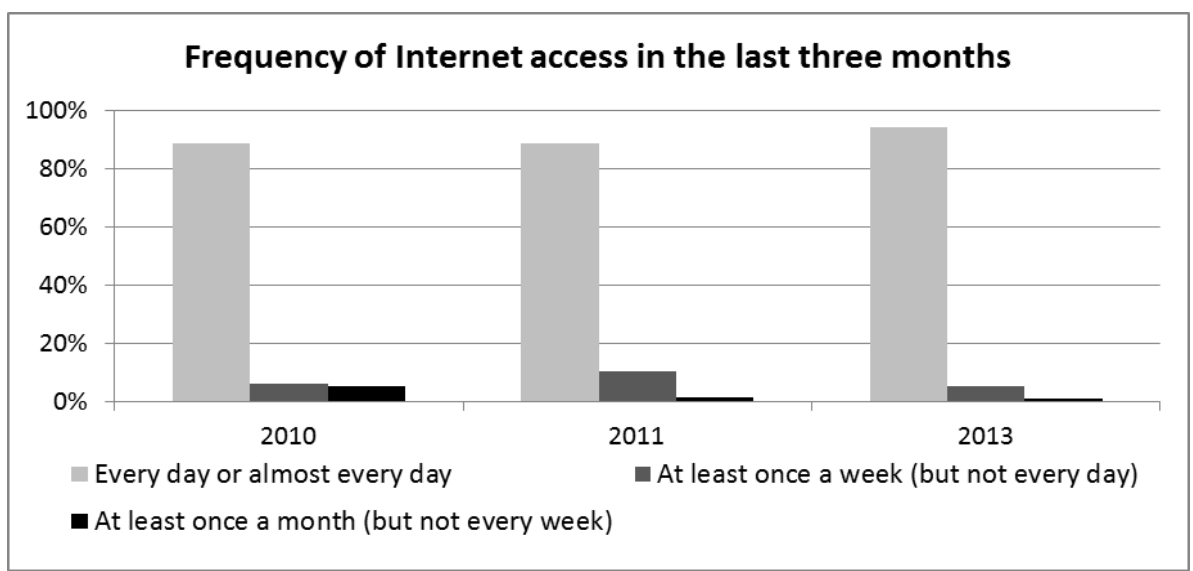

Figure 2. Frequency of Internet access in the last three months

Regarding the place of Internet use in the last three months, data show that students do that mostly from home (figure 3), $95.56 \%$ in 2013, but also from other people's house (41.48\% in 2013) and from their place of education (32.59\% in the same year). Comparing to the year 2010, the most important raise was the one concerning the use Internet from other people's house $(9.48 \%)$, than the one relating to the use of Internet from home $(8.06 \%)$, and finally from other places $(5,48 \%)$. There were no significant changes regarding the use of Internet from the place of education. The figures related to the use of BUSINESS SCHOOL, 2/2015, $32-48$ 
41 | TECHNOLOGY LEADERS OF COMPUTER AND WEB 2.0 USAGE IN HIGHER EDUCATION: CASE STUDY

Internet from a place of work (5.19\% in 2013) seem to show that this is not student's favorite place to access Internet, but if we take into consideration that only about $6 \%$ of all students are employed it is obvious that the situation is opposite.

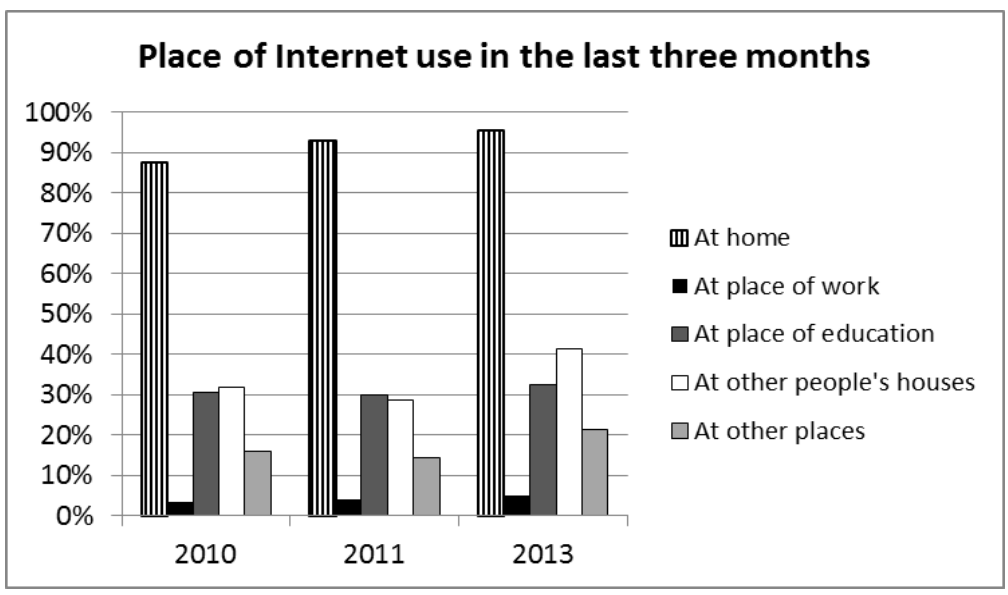

Figure 3. Place of Internet use in the last three months

On the topic of devices used for mobile Internet access (figure 4), there were no significant changes in the observed period. Students use the most $3 \mathrm{G}$ mobile phones (51.85\% in 2013) and handheld devices (38.52\%), laptops and notebooks away from home or work are next with $26.67 \%$. Comparing to the 2010 year this represents a growth of $10.85 \%$ for $3 \mathrm{G}$ mobile phone and $7.17 \%$ for laptops and notebooks away from home or work.

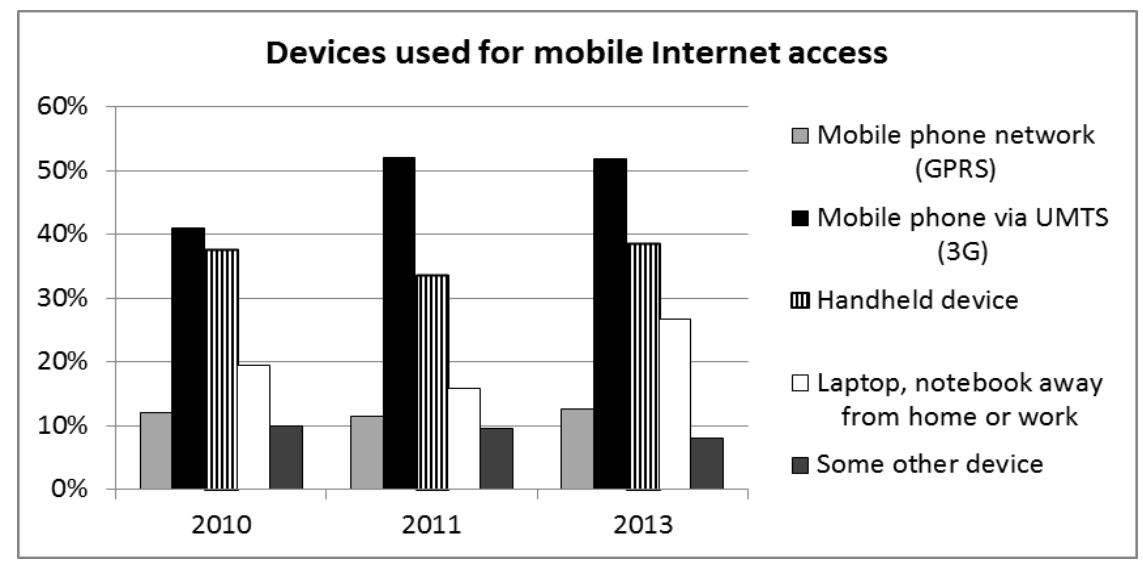

Figure 4. Devices used for mobile Internet access

The last field of research that authors will present is about student's Internet activities. The most popular activity in the last observed year (2013) was 
posting messages to social media sites, $83 \%$ comparing to $70 \%$ in 2010 . Top activities in are also sending/receiving e-mail (78.52\%), playing/downloading games, images, films or music (75.56\%), finding information about goods and services (64.44\%) and finding information for learning purpose (61.48\%). Activities that showed the most growth of popularity are reading/downloading online newspapers/news (58.52\% in 2013 comparing to $37.50 \%$ in 2010) and finding information about goods and services (64.44\% in 2013 comparing to $46.00 \%$ in 2010).

\section{SOCIAL WEB IN THE HIGHER EDUCATION INSTITUTION}

As authors already said, they gave students the task to make research in the subject they choose, using different Web 2.0 tools. This was the part of teaching process for Introduction in e-business in HBSNS. Some of the main results related to this research authors will describe in further text.

The main tool used in finding contents for their studies among all of them was Google. All students in this research used it as the beginning spot for entering to the other tools. When they had to translate their results to the Serbian language, they used Google Translate in almost all of the cases.

In 2010, authors found $46.3 \%$ of students that were using Wikipedia (figure 5). Next research in 2011 notified that even $98.04 \%$ of students used Wikipedia for finding relevant information. Finally, authors found that $91.4 \%$ of students used Wikipedia in 2013. Those high rates of Wikipedia usage are expected, because of the nature of information presented by this tool.

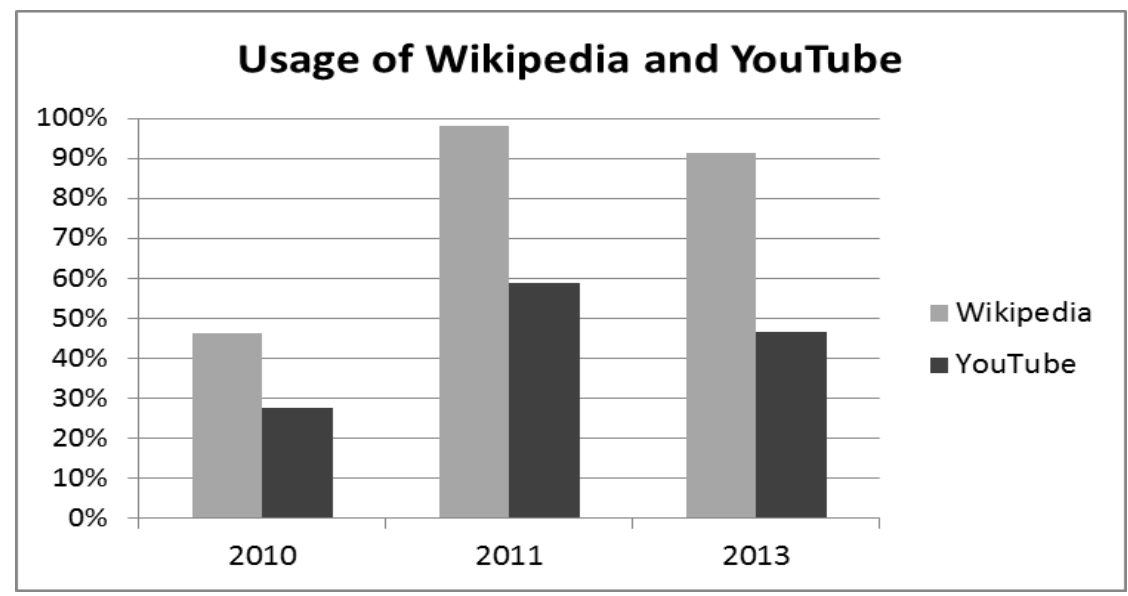

Figure 5. Usage of Wikipedia and YouTube

Next information authors did not expect: on the second place is YouTube, with $27.6 \%$ of student users in the first year, $58.80 \%$ in the second, and $46.7 \%$ in the BUSINESS SCHOOL, 2/2015, $32-48$ 
43 | TECHNOLOGY LEADERS OF COMPUTER AND WEB 2.0 USAGE IN HIGHER EDUCATION: CASE STUDY

last year of this research. The main reason why authors did not expect those high ranks of results is the fact that the multimedia information is not the common way to project presentation. Using YouTube, students had to type some contents, while all the other textual information they just copied and translated with automatic translators. The great popularity of YouTube is the main reason why so many students prefer using it.

Information about usage of Facebook in students' researches is in line with the penetration of this tool in Serbia (figure 6).

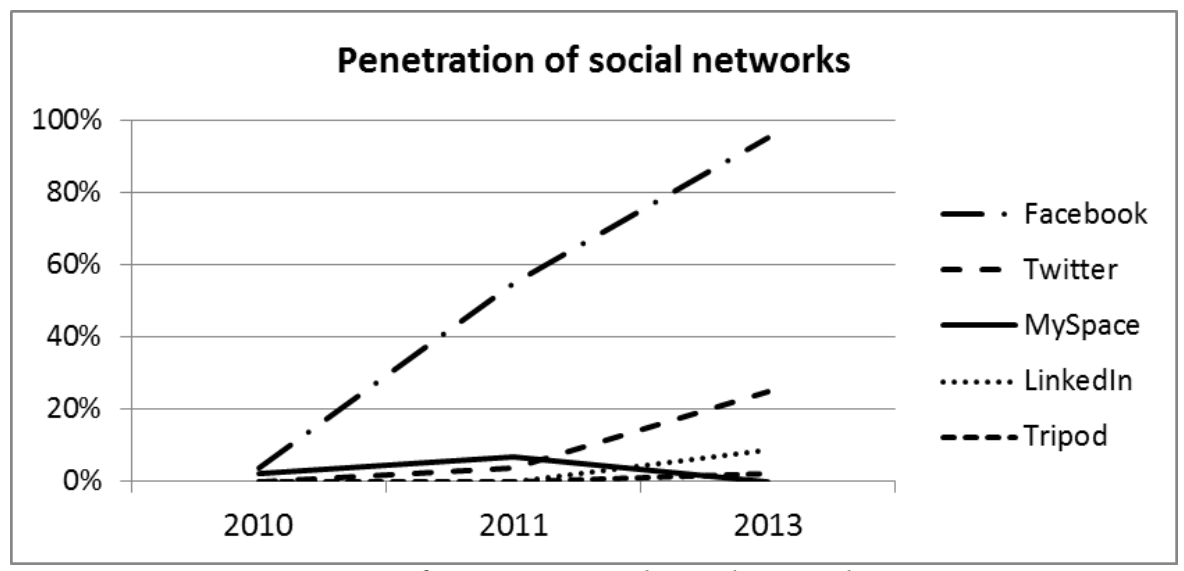

Figure 6. Penetration of social networks

In 2010, authors found only $3.7 \%$ of information taken from this social network, next year there were $54.90 \%$ of users among that group, while in 2013 authors registered that even $95.2 \%$ of students used Facebook for their research. Authors did not found any usage of Twitter in 2010, 3.7\% of them used Twitter for their research in 2011, while $24.9 \%$ of them used in the last research. Among the other social networks, students used $2.1 \%$ of students used MySpace in $2010,6.8 \%$ in 2011, while there were no users in 2013, but authors registered that $8.5 \%$ of them used LinkedIn and $2.1 \%$ used Tripod in this last year of the research.

Some kinds of surprises are the results that show the numbers of blogs users (figure 7).

Although authors expected, the number that is near the Wikipedia users, they found that only $13.5 \%$ in the first year of this research, $50.98 \%$ used different blogs in 2011 and $61.7 \%$ in 2013. Average numbers of used blogs among their users are 1.55 visits in 2010, 2.15 in 2011, and 3.24 in 2013. The only explanation for these results, which authors could offer, is the lower levels for this kind of information on Google lists. 


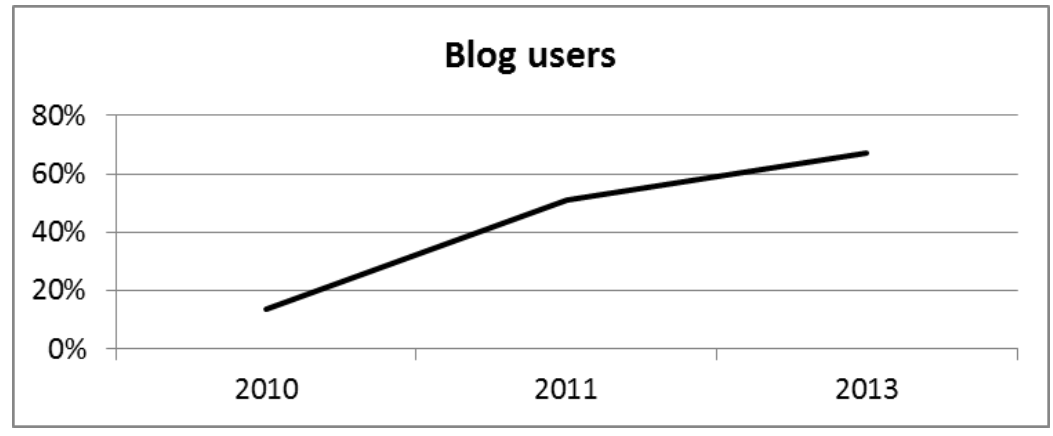

Figure 7. Blog users

Finally, authors found relatively lower number of students that used Flickr and Instagram (figure 8) - there are 8.7\% of Flickr users in 2010, 30.39\% in 2011 and $9.5 \%$ in 2013, while they registered $20.6 \%$ of Instagram users in 2013. Popularity of Flickr and Instagram among the students in Serbia is much lower than other social web services, where Instagram is strongly taking the leading position in this segment of usage.

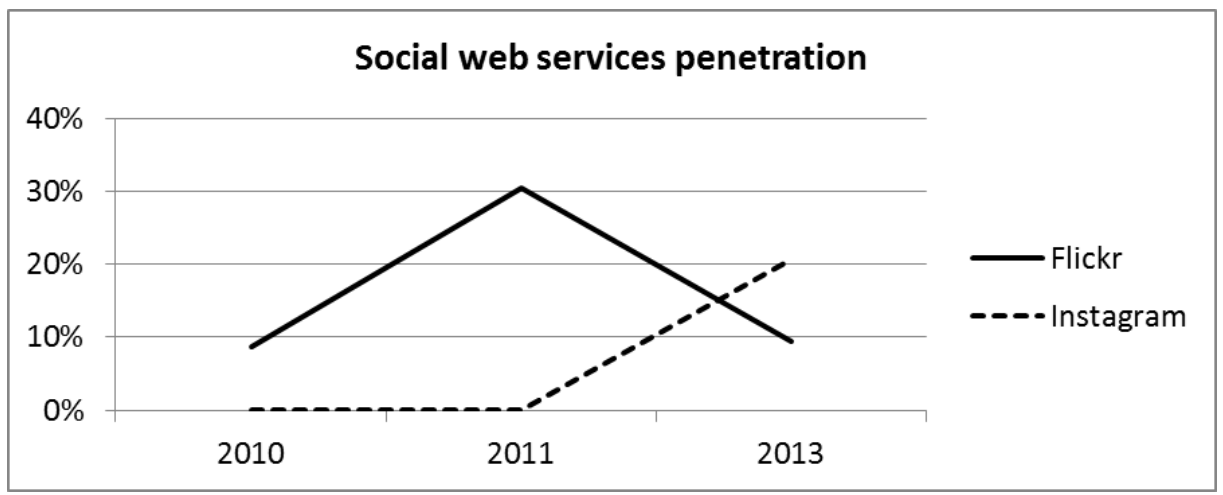

Figure 8. Social web services penetration

In the last research in 2013, authors found for the first time WikiMapia users, where $4.6 \%$ of students used this upcoming social web tool.

\section{DISCUSSION AND CONCLUSIONS}

Analyzing basic data regarding the use of Internet, authors conclude that students have excellent prerequisites to use features and tools designed to improve their education process. Almost all of them have access to Internet from their households. Those who cannot use Internet from home have the possibility to do it from our school. 

CASE STUDY

Great majority of examinee used Internet in the last three months and they did that every day or almost every day. When authors compare the percentages of our students referring to the last Internet use and the frequency of Internet access in the last three months with the same data for the students in the European Union (28 countries), they do not find any significant differences in the three investigated years.

In fact, authors find that figures are substantially different only for the indicator referring to the place of Internet use in the last three month, where the students from European Union accessed Internet from their place of education twice as much as their Serbian colleagues.

Our opinion is that students are adopting new ICT and tools easily, and they find ways to use them in different situations. This adoption is very democratic, because they are using all of them, no matter what is their main purpose. Authors also find that they have favorite tools, no matter what these tools are designed for. There are significantly more users of Wikipedia from YouTube, but that fact is relied with the aims of these tools. While Wikipedia is constructed to collect and present information mainly in textual form, information in Youtube is in the unsuitable form for the presentation in the form of project, but the popularity and ease of use of this multimedia tool is guiding significant group of students to choose Youtube contents for references in their projects.

An interesting fact is that authors find the same trends of their usage. The peak of their usage was in 2011, after that authors found the lower level of results for their usage. Authors find the reasons for that in the constant growth of blogs and especially high rate of social network usage. Their common conclusion for this group of results is that the participation picture of different social web tools is changing regarding their popularity. The results of this research are indicating that their choices about favorite Web 2.0 tools are changing according to their common popularity in the user's population.

Analyzing the world of social media usage, authors find that Serbia is mainly Facebook oriented. According to Surčulija et al. (2011), first four places on the list of the most popular social media networks, authors find Facebook on the first place, Youtube on the second, Blogger on the third, and Twitter on the fourth place. This trend of usage authors also find among the students in this group. From the dynamic perspective, MySpace loosed their popularity among the students, while the usage of Twitter shows constant growth. In the last year of the research, authors noticed the usage of relatively new social networks LinkedIn and Tripod. Those results present information that social networks usage has its leader, but there are significant practices of other tools. 
Similar situation is among the picture presentation tools, where the Picture from the real life is also reflected on the project results: the domination of Flickr is threatened in later years by the growing popularity of Instagram.

The results of this research also showed us that contents in finished projects were well structured and interesting, while multimedia contents brought a new dimension to these research results. These new project structures, where students have to use computers in order to form complete content, is spontaneously created by them, presuming that their mentors will accept it as a normal fact.

Finally, the time that they used for the creation of their projects was significantly lower from the time used for the classic research. The quality of their research was not analyzed, but the presentation of information was very interesting, with a lot of illustrations and pictures.

\section{REFERENCES}

Ahrens, A., Wen, M. L. Y., Huang, Y. H., Zascerinska, J., \& Bassus, O. (2010). A Comparative Study of the Relationship between Social Dimension of Web 2.0 Technologies and E-Learning: Students' View in Germany and Taiwan. Innovation and Entrepreneurship and its Implications in Engineering and Business Education. Philippines: Manila.

Amersdorffer, D., Bauhuber, F., \& Oellrich, J. (2012). The economic and cultural aspects of the social web: Implications for the tourism industry. Journal of Vacation Marketing. 18(3), 175-184.

Anderson, P. (2010). What is Web 2.0? Ideas, technologies and implications for education. Retrieved from http://www.scribd.com/doc/300024/What-isweb-20-Ideas-technologies-and-implications-Paul-Anderson.

Brusilovsky, P., \& Peylo, C. (2003). Adaptive and Intelligent Web-based Educational Systems, International Journal of Artificial Intelligence in Education, 13(2-4), 159-172.

Casey, G., \& Evans, T. (2011). Designing for Learning: Online Social Networks as a Classroom Environment. The International Review of Research in Open and Distance Learning, 12(7), 1-26.

Chi, H. (2012). Who Knows? Searching for Expertise on the Social Web. Communications of the ACM, 55(4), 110-110.

Chou, H. W., Chang, K. C., \& Lin, Y. H. (2013). Investigating Facebook and Google usage in Taiwan's college students. International Journal of Services Technology \& Management, 19(4-6), 201-218. 
47 | TECHNOLOGY LEADERS OF COMPUTER AND WEB 2.0 USAGE IN HIGHER EDUCATION: CASE STUDY

Devedžić, V. (2004). Education and the Semantic Web. International Journal of Artificial Intelligence in Education, 14(2), 165-191.

Fieseler, C., \& Fleck, M. (2013). The Pursuit of Empowerment through Social Media: Structural Social Capital Dynamics in CSR-Blogging. Journal of Business Ethics, 118(4), 759-775.

European Commission. Eurostat - Information Society Data Collection. Retrieved from

http://epp.eurostat.ec.europa.eu/portal/page/portal/information_society/int roduction/

Greenhow, C. (2007). What Teacher Education Needs to Know about Web 2.0: Preparing New Teachers in the 21st Century. In: R. Carlsen et al. (eds.), Proceedings of Society for Information Technology \& Teacher Education International Conference 2007 (pp. 1989-1992).

Hew, K. F., \& Cheung, W. S. (2013). Use of Web 2.0 Technologies in K-12 and Higher Education: The Search for Evidence-Based Practice. Educational Research Review, 9, 47-64.

Jošanov, B., Marošan, Z., \& Tomić, R. (2010). ICT as a Facilitator for eLearning 2.0 Implementation. In: Proceedings from IASK Teaching and Learning 2010 International Conference (pp. 734-738), Seville.

McLean, R., Richards, B. H., \& Wardman I. (2007). The effect of Web 2.0 on the future of medical practice and education: Darwikinian evolution or folksonomic revolution? Medical Journal of Australia, 187(3), 174-177.

O’Reilly, T. (2007). What is Social web: Design Patterns and Business Models for the Next Generation of Software. International Journal of Digital Economic, 65, 17-37.

Paavola, S., Lipponen, L., \& Hakkarainen, H. (2004). Models of Innovative Knowledge Communities and Three Metaphors of Learning. Review of Educational Research, 74(4), 557-576.

Peštek, A., Kadić-Maglajlić, S., \& Nožica, M. (2012). Implications of Web 2.0 Usage in Higher Education. International Journal of Management Cases, 14(1), 3-12.

Pritchett, C. C., Wohleb, E. C., \& Pritchett, C. G. (2013). Educators' Perceived Importance of Web 2.0 Technology Applications. TechTrends: Linking Research and Practice to Improve Learning, 57(2), 33-38.

Sangeeta Namdev, D. (2012). ICT and Web Technology Based Innovations in Education Sector. Turkish Online Journal of Distance Education, 13(4), 256-268. 
Sezen Balcikanli, G. (2012). Social Networking in Physical Education: Undergraduate Students' Views on Ning. Turkish Online Journal of Distance Education, 13(2), 277-290.

Sfard, A. (1998). On Two Metaphors for Learning and the Dangers of Choosing Just One. Educational Researcher, 27(2), 4-13.

Surčulija, J., Pavlović, B., \& Jovanović Padejski, Đ. (2011). Mapping Digital Media: Serbia: A Report of Open Society Foundation. Belgrade: Open Society Media Program.

Thackeray, R., Neiger, B. L., Hanson, C. L., \& McKenzie, J. F. (2008). Enhancing Promotional Strategies Within Social Marketing Programs: Use of Web 2.0 Social Media. Health Promotion Practice, 9(4), 338-343.

Turban, E., \& Volonino, L. (2010). Information Technology for Management. Denver, MA: John Wiley \& Sons.

Von Hippel, E. (2005). Democratizing Innovation. Cambridge. Massachusetts: MIT Press.

Wankel, L.A., \& Wankel, C. (2011). Higher Education Administration with Social Media. Bingley, UK: Emerald Group Publishing Limited.

Wellman, B., Salaff, J., Dimitrova, D., Garton, L., Gulia, M., \& Haythornthwaite, C. (1996). Computer-Supported Social Networks. Annual Review of Sociology, 22, 213-238.

Wiley, D. (2010). Openness as Catalyst for an Educational Reformation. EDUCAUSE Review, 45(4), 14-2.

Received: 09.03.2016. Accepted: 17.03.2016. 